Research article

\title{
Integrated fixed-film activated sludge membrane bioreactors versus membrane bioreactors for nutrient removal: A comprehensive comparison
}

\author{
Giorgio Mannina ${ }^{\mathrm{a}, \mathrm{b}, *}$, George A. Ekama ${ }^{\mathrm{c}}$, Marco Capodici ${ }^{\mathrm{a}}$, Alida Cosenza ${ }^{\mathrm{a}}$, Daniele Di Trapani ${ }^{\mathrm{a}}$, \\ Hallvard Ødegaard ${ }^{\mathrm{d}}$
}

a Dipartimento di Ingegneria Civile, Ambientale, Aerospaziale, dei Materiali, Università di Palermo, Viale delle Scienze, Ed. 8, 90100, Palermo, Italy

${ }^{\mathrm{b}}$ Department of Earth and Environmental Engineering, Columbia University, 500 West 120th Street, New York, NY 10027, USA

${ }^{\mathrm{c}}$ Water Research Group, Department of Civil Engineering, University of Cape Town, Rondebosch, 7700, Cape, South Africa

d NTNU - Norwegian University of Science and Technology, Department of Hydraulic and Environmental Engineering, 7491, Trondheim, Norway

\section{A R T I C L E I N F O}

\section{Keywords:}

Nutrient removal

Greenhouse gases

Respirometry

Biofilm

Membrane fouling

\begin{abstract}
A B S T R A C T
This research elucidates the pollutants (nutrients and carbon) removal performance and nitrous oxide $\left(\mathrm{N}_{2} \mathrm{O}\right)$ emissions of two pilot plants. Specifically, a University of Cape Town (UCT) Membrane Bioreactor (MBR) plant and an Integrated Fixed Film Activated Sludge (IFAS)-UCT-MBR plant were investigated. The plants were fed with real wastewater augmented with acetate and glycerol in order to control the influent carbon nitrogen ratio $(\mathrm{C} / \mathrm{N})$. The short-term effect of the inlet $\mathrm{C} / \mathrm{N}$ ratio variation $(\mathrm{C} / \mathrm{N}=5 \mathrm{mgCOD} / \mathrm{mgN}$ and $\mathrm{C} / \mathrm{N}=10 \mathrm{mgCOD} /$ $\mathrm{mgN}$ ) on the behaviour of both plants was investigated. The results showed that the IFAS-UCT-MBR configuration provided the best performance in terms of pollutants removal at the two investigated $\mathrm{C} / \mathrm{N}$ ratios. Furthermore, the lowest $\mathrm{N}_{2} \mathrm{O}$ emission (with respect to the influent nitrogen) was observed in the IFAS-UCT-MBR configuration, thus suggesting a potential beneficial effect of the biofilm in the emission reduction. However, the membrane of the IFAS-UCT-MBR showed a greater fouling tendency compared to the UCT-MBR configuration. This result, likely related to the biofilm detached from carriers, could seriously affect the indirect GreenHouse Gas emissions due to the increase of the energy requirement for permeate extraction with the increase of membrane fouling.
\end{abstract}

\section{Introduction}

It is well known that nutrients conveyed with wastewater (either raw or treated), like nitrogen $(\mathrm{N})$ and phosphorus $(\mathrm{P})$ compounds, might produce negative effects on the receiving water bodies, affecting their quality level. High concentration of nutrients can promote eutrophication as well as direct toxicity for the aquatic organisms (Wang et al., 2006). Therefore, tertiary treatment for $\mathrm{N}$ and $\mathrm{P}$ removal from wastewater becomes a prominent requirement especially when discharging into "sensitive areas". In the last years, biological nutrient removal (BNR) processes have been thoroughly investigated. BNR processes have several advantages compared to the chemical processes (for P-removal), in terms of chemical consumption, energy requirements and production of chemical sludge.

Traditionally, BNR is carried out by combining anaerobic, anoxic and aerobic conditions within separate reactors (Naessens et al., 2012). Nitrogen removal is usually achieved by the joint activity of ammonia oxidizing bacteria (AOB) and nitrite oxidizing bacteria (NOB) for nitrification. Heterotrophic organisms generally handle denitrification. In contrast, biological phosphorus removal relies on the ability of phosphorus accumulating organisms (PAOs) to accumulate $\mathrm{P}$ as intracellular polyphosphate under the alternation of anaerobic/aerobic condition. Conventional activated sludge (CAS) processes have been proven to be effective for the removal of organic carbon and nutrients. However, an important drawback of CAS systems is the required significant volumes, making CAS solution expensive. Moreover, the overall efficiency strongly depends on the performance of the final settler for solid-liquid separation, which may suffer of many separation problems (Wanner, 2002).

Therefore, new advanced technologies were explored by the scientific community over the last years. Among the innovative technologies, the combination of membrane bioreactor (MBR) and moving bed biofilm reactor (MBBR) introduced two different ways for the improvement of the system performance: (a) the use of membrane for the solid-

\footnotetext{
${ }^{*}$ Corresponding author. Dipartimento di Ingegneria Civile, Ambientale, Aerospaziale, dei Materiali, Università di Palermo, Viale delle Scienze, Ed. 8, 90100, Palermo, Italy.

E-mail address: giorgio.mannina@unipa.it (G. Mannina).
} 
liquid separation and (b) the use of suspended carriers for biofilm growth inside the bioreactor (Leiknes and Ødegaard, 2007; Leyva-Díaz et al., 2016a; Yang et al., 2014). When operated in a hybrid configuration, thus enhancing the simultaneous growth of activated sludge and biofilm, these systems are usually referred to as MBBR-based Integrated Fixed Film Activated Sludge (IFAS) membrane bioreactors (IFAS-MBR) (Mannina et al., 2017b).

There are several advantages of using IFAS compared to CAS (Ødegaard et al., 2014; Ødegaard, 2017). The main benefit of IFAS is that nitrification can be obtained at less than half of the (Mixed Liquor Sludge Retention Time) $\mathrm{SRT}_{\mathrm{MLSS}}$ than that required in CAS systems. Moreover, at low SRT $_{\text {MLSS }}$ more carbon will be available for denitrification through hydrolysis of the MLSS. Several studies have shown that the specific denitrification rate in IFAS systems is around twice that of CAS systems (Onnis-Hayden et al., 2007; Rusten et al., 2003). Hence, the IFAS-MBR systems require a smaller volume for nitrification and denitrification than conventional MBR systems. The combination of IFAS and MBR has several advantages compared to the CAS or MBR systems.

Feng et al. (2016) highlighted sludge yield reduction, denitrification increase and decrease of membrane fouling in a system combining MBBR and MBR. Leyva-Díaz and co-workers (Leyva-Díaz et al., 2013) observed higher nitrification-denitrification in a IFAS-MBR system compared to a traditional MBR; they underlined the potential occurrence of the simultaneous nitrification-denitrification within the biofilm. IFAS-MBR systems are relatively new; therefore, further experiments are required in order of improving knowledge. The influent carbon-to-nitrogen $(\mathrm{C} / \mathrm{N})$ ratio may affect the performance of the system, referring in particular to the nitrification-denitrification processes (Fu et al., 2009). This aspect is of paramount importance concerning greenhouse gas (GHG) emission, referring in particular to nitrous oxide $\left(\mathrm{N}_{2} \mathrm{O}\right)$ since it is mainly produced during nitrogen removal processes (Kampschreur et al., 2009). Nevertheless, only few studies have been carried out with this regard in MBR-biofilm systems so far (Mannina et al., 2017a; Todt and Dörsch, 2016).

The goal of the present paper is to compare the performance of two different MBR pilot plants realized according to the University of Cape Town (UCT) layout (namely, IFAS-UCT-MBT and UCT-MBR).

In particular, this study analyses the short-term effect of the influent $\mathrm{C} / \mathrm{N}$ variation (Phase $\mathrm{I}-\mathrm{C} / \mathrm{N}=5$; Phase $\mathrm{II}-\mathrm{C} / \mathrm{N}=10$ ) on organic carbon and nutrient removal, biomass respiratory activity and membrane fouling propensity. Moreover, the paper aims at assessing the overall $\mathrm{N}_{2} \mathrm{O}$ emissions from both UCT-MBR and IFAS-UCT-MBR systems, evaluating the $\mathrm{C} / \mathrm{N}$ variation and elucidating the potential beneficial role played by the biofilm presence. The novelty aspects of the present study are represented by a focus on $\mathrm{N}_{2} \mathrm{O}$ production/emission as well as sludge dewaterability features in MBR systems with and without the biofilm presence, scarcely investigated in previous studies.

\section{Materials and methods}

\subsection{The pilot plant}

Two pilot plants were analysed: a UCT-MBR and a IFAS-UCT-MBR (Fig. 1). Both pilot plants have the same layout according to the UCTMBR scheme. More precisely, three reactors in series (anaerobic, anoxic and aerobic) were followed by a membrane reactor (MBR). Inside the membrane reactor an ultrafiltration hollow fiber membrane module (Koch Puron ${ }^{\circ} 3$ bundle) (pore size of $0.03 \mu \mathrm{m}$ and membrane net area of $1.4 \mathrm{~m}^{2}$ ) was located. For both pilot plants the reactors have the same volume. The key difference between the two pilot plants is the presence, only for the IFAS-UCT-MBR plant, of suspended plastic carriers (Amitech, density $=0.95 \mathrm{~g} \mathrm{~cm}^{-3}$; specific surface $=500 \mathrm{~m}^{2} \mathrm{~m}^{-3}$ ). These carriers were inserted only inside the aerobic (filling ratio of $40 \%$ ) and anoxic (filling ratio of 15\%) tanks. The presence of carriers makes quite different the behaviour of biological processes inside the aerobic and anoxic tanks of the IFAS-UCT-MBR plant compared to the UCT-MBR plant due to the combined effect of suspend biomass and biofilm.

Permeate flow rate was equal to $20 \mathrm{Lh}^{-1}\left(\mathrm{Q}_{\mathrm{IN}}\right)$. The mixed liquor $\left(\mathrm{Q}_{\mathrm{R} 1}, 20 \mathrm{~L} \mathrm{~h}^{-1}\right)$ from the anoxic to the anaerobic tank was continuously recycled. Furthermore, a $100 \mathrm{~L} \mathrm{~h}^{-1}$ flow rate $\left(\mathrm{Q}_{\mathrm{R} 2}\right)$ of mixed liquor was pumped from the aerobic to the MBR tank. The membrane was periodically backwashed (every $10 \mathrm{~min}$ for a period of $1 \mathrm{~min}$ ) by pumping, from the Clean In Place (CIP) tank a volume of permeate back through the membrane module $\left(\mathrm{Q}_{\mathrm{BW}}\right)$. The net permeate flow rate discharged was equal to $20 \mathrm{Lh}^{-1}$ (Q out). Activated sludge was also continuously recycled from the MBR to the anoxic tank through the oxygen depletion reactor (ODR) tank sludge $\left(80 \mathrm{Lh}^{-1}, \mathrm{Q}_{\mathrm{RAS}}\right)$. The ODR has the function of reducing the amount of dissolved oxygen recycled from the MBR to the anoxic tank. The covers on the anaerobic, anoxic, aerobic and MBR reactors allowed the collection of the off-gas produced from each reactor.

Municipal wastewater was treated within both pilot plants. However, the inlet $\mathrm{C} / \mathrm{N}$ ratio was controlled by adding a synthetic mixture to the municipal wastewater (composed by sodium acetate, glycerol, dipotassium hydrogen phosphate, and ammonium chloride).

For both configurations, the experimental campaign was divided into two phases: $i$. the influent $\mathrm{C} / \mathrm{N}$ was equal to $5 \mathrm{mgCOD} / \mathrm{mgN}$; ii. the influent $\mathrm{C} / \mathrm{N}$ was equal to $10 \mathrm{mgCOD} / \mathrm{mgN}$.

The average inlet COD concentration for the UCT-MBR was equal to $411 \mathrm{mg} \mathrm{L}^{-1}$ (58\% coming from synthetic wastewater) and $502 \mathrm{mg} \mathrm{L}^{-1}$ (78\% coming from synthetic wastewater) for the experimental phase at $\mathrm{C} / \mathrm{N}$ equal to 5 and $10 \mathrm{mgCOD} / \mathrm{mgN}$, respectively (Mannina et al., 2017b). The average inlet total nitrogen (TN) concentration for the UCT-MBR was equal to $99 \mathrm{mg} \mathrm{L}^{-1}$ (52\% coming from synthetic wastewater) and $52.6 \mathrm{mg} \mathrm{L}^{-1}$ for the experimental phase at $\mathrm{C} / \mathrm{N}$ equal to 5 and $10 \mathrm{mgCOD} / \mathrm{mgN}$, respectively. The ammonium chloride has been added only for the UCT-MBR plant during the experimental campaign at $\mathrm{C} / \mathrm{N}$ equal to $5 \mathrm{mgCOD} / \mathrm{mgN}$ (Mannina et al., 2017b). While, the average inlet COD concentration for the IFAS-UCT-MBR was equal to $543 \mathrm{mg} \mathrm{L}^{-1}$ (56\% coming from synthetic wastewater) and $864 \mathrm{mg} \mathrm{L}^{-1}$ (73\% coming from synthetic wastewater) for the experimental phase at $\mathrm{C} / \mathrm{N}$ equal to 5 and $10 \mathrm{mgCOD} / \mathrm{mgN}$, respectively (Mannina et al., 2017c). The average inlet total nitrogen (TN) concentration for the IFAS-UCT-MBR was equal to $92 \mathrm{mg} \mathrm{L}^{-1}$ and $80 \mathrm{mg} \mathrm{L}^{-1}$ for the experimental phase at $\mathrm{C} / \mathrm{N}$ equal to 5 and $10 \mathrm{mgCOD} / \mathrm{mgN}$, respectively (Mannina et al., 2017c).

The UCT-MBR plant was operated at a mixed liquor sludge retention time ( $\mathrm{SRT}_{\mathrm{MLSS}}$ ) of 50 days at the influent $\mathrm{C} / \mathrm{N}=5 \mathrm{mgCOD} / \mathrm{mgN}$ and 40 days at the influent $\mathrm{C} / \mathrm{N}=10 \mathrm{mgCOD} / \mathrm{mgN}$. The IFAS-UCT-MBR plant was operated at $\mathrm{SRT}_{\mathrm{MLSS}}$ of 65 days at the influent $\mathrm{C} / \mathrm{N}=5 \mathrm{mgCOD} /$ $\mathrm{mgN}$ and 40 days at the influent $\mathrm{C} / \mathrm{N}=10 \mathrm{mgCOD} / \mathrm{mgN}$. It should be noted that these SRT's are much higher than what would normally be used in practice - especially for the IFAS-UCT- MBR case and the potential for smaller foot-print by the use of IFAS-UCT-MBR as compared to MBR could not be analysed in this investigation.

\subsection{Analytical methods}

During the experimental campaign, samples were collected two times per week from the influent, effluent and intermediate sections of both plants. The samples were analysed using Standard Methods (APHA, 2012) for: chemical oxygen demand (COD), biochemical oxygen demand (BOD), total nitrogen (TN), ammonium nitrogen $\left(\mathrm{NH}_{4}-\mathrm{N}\right)$, nitrate nitrogen $\left(\mathrm{NO}_{3}-\mathrm{N}\right)$, nitrite nitrogen $\left(\mathrm{NO}_{2}-\mathrm{N}\right)$, orthophosphate $\left(\mathrm{PO}_{4}-\mathrm{P}\right)$.

Furthermore, the nitrification ( $\left.\eta_{\text {nit }}\right)$, denitrification ( $\left.\eta_{\text {denit }}\right)$ and total nitrogen $\left(\eta_{\text {Ntotal }}\right)$ removal efficiencies were evaluated according to (Mannina et al., 2017c). In order to discriminate between the COD removal due to the biological processes and the physical effect of membrane, the following removal efficiencies were evaluated according to (Mannina et al., 2017c): biological removal efficiency ( $\eta_{\text {BIO }}$ ); 
(a)

UCT-MBR

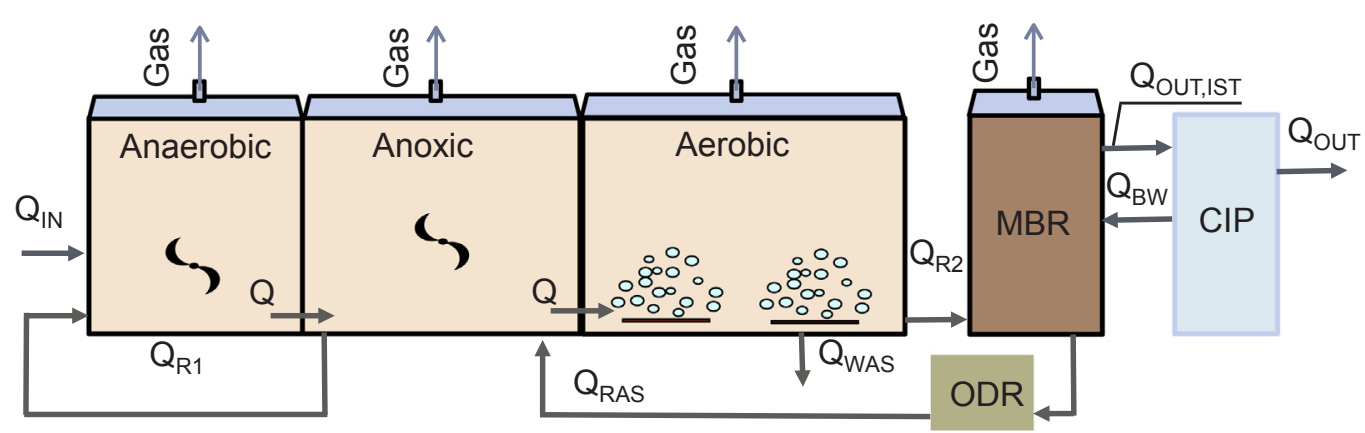

(b)

IFAS-UCT-MBR

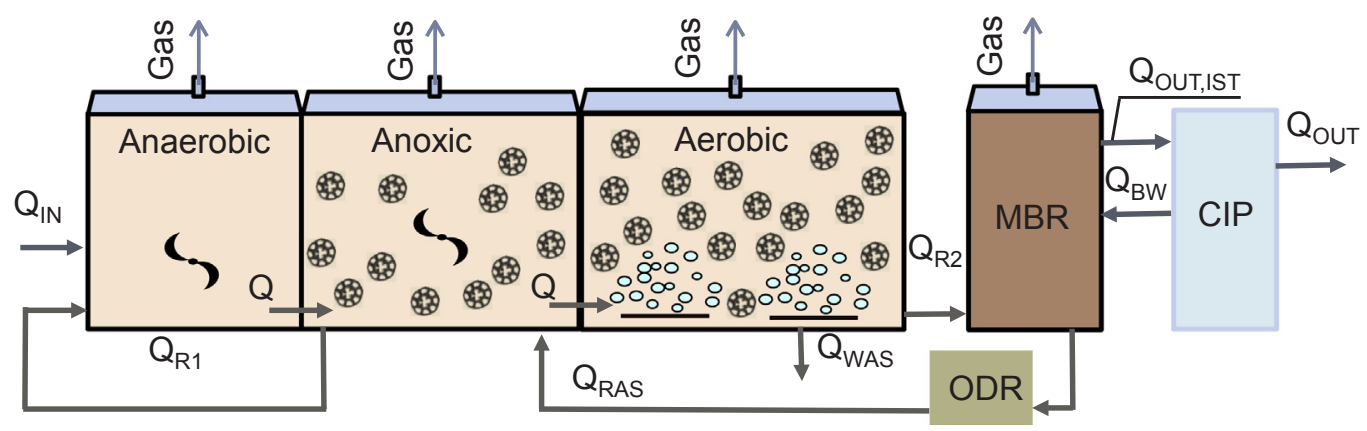

Fig. 1. Pilot plant layout for the UCT-MBR (a) and IFAS-UCT-MBR (b) configuration; where, $Q_{I N}=$ inlet flow rate; $Q_{R 1}=$ flow rate recycled from the anoxic to the anaerobic tank; $\mathrm{Q}_{\mathrm{R} 2}=$ flow rate pumped from the aerobic to the membrane tank; $\mathrm{Q}_{\mathrm{RA}} \mathrm{s}=$ recycle activated sludge line; $\mathrm{Q}_{\mathrm{WAS}}=$ waste sludge flow rate; QouT,IST $=$ instantaneous permeate flow rate; $\mathrm{Q}_{\mathrm{BW}}=$ backwashing permeate flow rate; QouT $=$ net permeate flow rate; ODR = oxygen depletion reactor; $\mathrm{V}_{\mathrm{ANAER}}=$ volume of the anaerobic reactor $=62 \mathrm{~L} ; \mathrm{V}_{\mathrm{ANOX}}=$ volume of the anoxic reactor $=102 \mathrm{~L} ; \mathrm{V}_{\mathrm{AER}}=$ volume of the aerobic reactor $=221 \mathrm{~L} ; \mathrm{V}_{\mathrm{MBR}}=$ volume of the membrane tank $=32 \mathrm{~L}$.

physical removal efficiency ( $\left.\eta_{\mathrm{PHYS}}\right)$. The sum between $\eta_{\mathrm{BIO}}$ and $\eta_{\mathrm{PHYS}}$ provided the total COD removal efficiency $\left(\eta_{\text {Tот }}\right)$ (Mannina et al., 2017c).

Respirometric batch tests were also performed during the pilot plants monitoring according to Mannina et al. (2017c). Briefly, the growth rate $\left(\mu_{\mathrm{H}}\right.$ and $\mu_{\mathrm{A}}$ for heterotrophic and autotrophic bacteria, respectively), the yield coefficient $\left(\mathrm{Y}_{\mathrm{H}}\right.$ and $\mathrm{Y}_{\mathrm{A}}$ for heterotrophic and autotrophic bacteria respectively) and the half saturation coefficient $\left(\mathrm{K}_{S}\right.$ and $K_{N}$ for organic substrate and for nitrogen respectively) were assessed and compared together with decay rate $\left(\mathrm{b}_{\mathrm{H}}\right)$, specific oxygen uptake rate (SOUR) etc.

Biomass samples collected from the aerobic and anoxic reactors were used to perform the respirometric batch tests; for the IFAS-UCTMBR configuration, biofilm samples were also adopted. Details on the respirometric batch tests operation can be find in literature (Di Trapani et al., 2015; Mannina et al., 2017c).

Extracellular polymeric substances (EPS) were extracted according to the procedure reported in literature (Mannina et al., 2016). According to the aforementioned procedure the total EPS (EPS ${ }_{\mathrm{T}}$ ) where fractionated into bound EPS (EPS Bound $_{\text {) }}$ and soluble microbial products (SMP) (Equation (1)).

$E P S_{T}=\underbrace{E P S_{P}+E P S_{C}}_{E P S}+\underbrace{S M P_{P}+S M P_{C}}_{E P S}$

where the subscripts " $\mathrm{P}$ " and " $\mathrm{C}$ " indicate the content of proteins and carbohydrates respectively in the EPS Bound $_{\text {and SMP, that typically }}$ constitute the main fractions. Furthermore, the measured EPS concentration were normalized, referred to the MLSS concentration, and expressed as mgEPS.gTSS ${ }^{-1}$.

Mixed liquor samples were collected weekly from each reactor and analysed in order to assess the sludge dewaterability features of both configurations during Phases I and II.

The sludge dewaterability features, in terms of capillary suction time (CST) and specific resistance to filtration (SRF) in vacuum conditions $(-50 \mathrm{k} \mathrm{pa})$ were assessed in accordance with (Capodici et al., 2016).

\subsection{Nitrous oxide analysis}

Gas samples were withdrew from each reactor (anaerobic, anoxic, aerobic and MBR) two times per week. Samples were analysed by using a gas chromatograph (GC) equipped with an electron capture detector (ECD) in order to assess the nitrous oxide concentration $\left(\mathrm{N}_{2} \mathrm{O}\right)$.

Dissolved $\mathrm{N}_{2} \mathrm{O}$ concentration was also measured from liquid samples withdrawn from the anaerobic, anoxic, aerobic, ODR and MBR reactors and permeate (Kimochi et al., 1998). Details on the gas sampling and $\mathrm{N}_{2} \mathrm{O}$ concentration measuring can be find in literature (Mannina et al., 2017a, 2017b; Tsuneda et al., 2005). The off-gas exiting velocity (from each reactor) has been measured by adopting the TMA 21HW Hot Wire anemometer; therefore, the gas flux was evaluated.

\subsection{Membrane fouling monitoring}

In order to monitor membrane fouling the transmembrane pressure (TMP) and the permeate flux (J) were measured during the pilot plant operation. Both TMP and $\mathrm{J}$ were used to evaluate the membrane resistance $\left(\mathrm{R}_{\mathrm{T}}\right)$ (Equation (2)).

$R_{T}=\frac{T M P}{\mu J}$

where $\mu$ is the permeate viscosity. 
$\mathrm{R}_{\mathrm{T}}$ was fractionated into four major components by using the in series method (Equation (3)) (Di Trapani et al., 2014; Mannina et al., 2016).

$R_{F}=R_{P B}+R_{C, \text { irr }}+R_{C, \text { rev }}=R_{T}-R_{m}$

where: $R_{F}$ is the resistance due to the membrane fouling; $R_{P B}$ is the irreversible resistance due to colloids and particles deposition into the membrane pore; $R_{C, \text { irr }}$ is the fouling resistance related to superficial cake deposition that can only be removed by physical cleaning (hydraulic/sponge scrubbing); $\mathrm{R}_{\mathrm{C} \text {,rev }}$ is the fouling resistance related to superficial cake deposition that can be removed by ordinary backwashing; $R_{m}$ is the intrinsic resistance of membrane.

\section{Results and discussion}

\subsection{Removal performances}

\subsubsection{Carbon removal}

Membrane filtration contributed throughout the whole experimentation to the achievement of high COD removal efficiencies. Conversely, the biological performance $\left(\eta_{\mathrm{BIO}}\right)$ resulted affected by the operated layout. The biological COD removal efficiency increased with the $\mathrm{C} / \mathrm{N}$ ratio fed to the pilot plant and the highest efficiency occurred during the IFAS-UCT-MBR showing the contribution of the biofilm to the carbon removal process.

Fig. 2 shows the average values of the COD, $\mathrm{N}$ and $\mathrm{P}$ removal achieved in Phase I and Phase II in the UCT-MBR and in the IFAS-UCTMBR configuration. As noticeable from Fig. 2a and b, both systems were able to provide excellent total COD removal efficiencies throughout experiments, with average removals of 98 for both the UCT-MBR and the IFAS-UCT-MBR. The influence of the $\mathrm{C} / \mathrm{N}$ ratio on carbon removal resulted scarce. Indeed during each experimental phase the total carbon, expressed as COD, removal efficiency resulted on average higher than 98\% with both configuration. Leyva-Díaz et al. (2013) carried out a comparison between MBR and hybrid MBR with similar filling fraction in the aerobic reactor and similar hydraulic retention time (HRT) values, achieving in general similar organic matter removal. In contrast, the removal efficiencies achieved in the present study were slight higher compared to what observed by Feng et al. (2016) in an experimental campaign carried out on two hybrid membrane bioreactors (with different carriers for biofilm growth). This result might be related to the fact that in the experiments by Feng et al. (2016), carried at low C/N ratio (3-5), the plants were operated at a lower HRT and the membrane pore size was slight higher compared to the present study $(0.1 \mu \mathrm{m}$ vs $0.03 \mu \mathrm{m})$.

In contrast, the inlet $\mathrm{C} / \mathrm{N}$ ratio showed a more pronounced effect on the biological COD removal performance (as evaluated prior to membrane filtration). Indeed, for the UCT-MBR system, the average removal efficiency increased from $74 \%$ up to $83 \%$, during $\mathrm{C} / \mathrm{N}=5$ and $\mathrm{C} /$ $\mathrm{N}=10$ respectively. The increase in $\mathrm{C} / \mathrm{N}$ resulted thus in a $9 \%$ more of biological removal efficiency. The lowest $\mathrm{C} / \mathrm{N}$ ratio influenced the activity level of the heterotrophic bacteria, as outlined in section 3.2. The IFAS-UCT-MBR pilot plant showed a similar increase of the biological COD removal from Phase I to Phase II. However, it is worth noting that in Phase I $(\mathrm{C} / \mathrm{N}=5)$, the IFAS-UCT-MBT pilot plant was able to provide a higher removal efficiency (80\%) compared with that observed in the UCT-MBR system (74\%). This different behaviour is likely due to the biofilm presence in the anoxic and aerobic reactors of the IFAS-UCTMBR plant that contributed to the overall biological performance of the system (Leyva-Díaz et al., 2016b).

Nevertheless, the obtained results confirmed the high robustness of both MBR/IFAS-MBR configurations for the organic matter removal, similar to those achieved in previous studies carried out on similar plant layouts (Cuevas-Rodríguez et al., 2015; Leyva-Diaz and Poyatos, 2015; Leyva-Díaz et al., 2016b).

\subsubsection{Nitrogen removal}

Concerning the nitrogen removal, both systems showed an increasing nitrification efficiency with the increase of the inlet $\mathrm{C} / \mathrm{N}$ ratio (Fig. 2b and c). With a $\mathrm{C} / \mathrm{N}$ ratio of 5 , both systems showed a nitrification efficiency close to $81 \%$ (average value). In contrast, with a $\mathrm{C} / \mathrm{N}$ of 10 the UCT-MBR delivered a nitrification efficiency higher than $95 \%$ on average, while the IFAS-UCT-MBR showed a slight lower nitrification efficiency, close to $91 \%$ on average, with the result that apparently the carriers do not give any advantage to the IFAS-UCT-MBR system over the UCT-MBR system. However, the ammonium loading rate was higher in the IFAS-UCT-MBR pilot plant at $805 \mathrm{mgNH}_{4}-\mathrm{N} \mathrm{d}^{-1}$ compared with $674 \mathrm{mgNH}_{4}-\mathrm{N} \mathrm{d}^{-1}$ in the UCT-MBR pilot plant. Therefore, in terms of ammonium load nitrified, the IFAS-UCT-MBR showed a better performance, highlighting the important role played by the attached biomass in the nitrification process. Indeed, the biofilm developed on the suspended carriers, characterized by a high retention time, enabled the growth of autotrophic specie that sustained the high nitrification performance showed by the IFAS-UCT-MBR plant.

Moreover, the nitrification rate values allow to stress the relevant contribution of the biofilm to the nitrification process. Indeed, referring in particular to the IFAS configuration, the nitrification rates in Phase I (C/ $\mathrm{N}$ ratio of 5) were 4.29 and $4.77 \mathrm{mgNH}_{4} \mathrm{~L}^{-1} \mathrm{~h}^{-1}$ for biofilm and suspended biomass. In contrast, in Phase II (C/N ratio of 10$)$ they were 5.78 and $1.58 \mathrm{mgNH}_{4} \mathrm{~L}^{-1} \mathrm{~h}^{-1}$ for biofilm and suspended biomass, highlighting the key role played by the biofilm (characterized by very high residence time and thus rich in nitrifying species) towards nitrification when a higher organic loading rate promoted a high competition between autotrophs and heterotrophs in the mixed liquor. This excellent nitrification performance is in good agreement with what observed by Feng et al. (2016).

In terms of denitrification and total nitrogen removal, both systems showed similar behaviour, with a general performance increase with the increase of the $\mathrm{C} / \mathrm{N}$ ratio. Indeed, the lower $\mathrm{C} / \mathrm{N}$ ratio apparently caused carbon limitation to the heterotrophic organisms, thus contributing to lower the system performance. Nevertheless, at $\mathrm{C} / \mathrm{N}=5$ the IFAS-UCT-MBR pilot plant showed a better performance compared to the UCT-MBR one ( $43 \%$ vs $32 \%$, on average). The presence of suspended carriers in the anoxic compartment could enhance endogenous denitrification processes within the biofilm, thus improving the system performance. In terms of nitrogen removal, both systems showed performances in good agreement with previous studies (Leyva-Díaz et al., 2016a), with average removal efficiency of $69 \%$ for both pilot plants with a $\mathrm{C} / \mathrm{N}$ ratio of 10 .

Globally, the nitrogen removal resulted enhanced in the IFAS-UCTMBR due to the co-presence of suspended and attached biomass. Indeed, in the IFAS-UCT-MBR configuration within biofilm aerobic and anoxic zones can be formed thus improving the total nitrogen removal. Similar results were also obtained by Leyva-Díaz et al. (2016b). During the $\mathrm{C} / \mathrm{N}=5$ period the contribution of biofilm to the nitrogen removal process increased, on average, from $39 \%$ to $53 \%\left(\eta_{\text {Ntot }}\right.$ for UCT-MBR and IFAS-UCT-MBR respectively).

\subsubsection{Phosphorus removal}

In Fig. 2 results of the average $\mathrm{P}^{-\mathrm{PO}_{4}}$ removal efficiency (Fig. 2e) and the average concertation of $\mathrm{P}$ released/taken up $\mathrm{P}_{-} \mathrm{PO}_{4}$ concentration (Fig. 2f) for each configuration and $\mathrm{C} / \mathrm{N}$ value are reported.

In details, as far as the $\mathrm{C} / \mathrm{N}$ ratio was set at 5 , a carbon limitation phenomenon severely affected the biological denitrification and, due to this reason, nitrates were recycled to the anaerobic reactor. The anaerobic reactor acted, therefore, as an anoxic reactor, thus affecting the biological phosphorous removal process in the UCT-MBR configuration. Conversely, during the IFAS-UCT-MBR period the biofilm presence yielded to an improvement of phosphorous removal efficiency (up to $87 \%)$. 

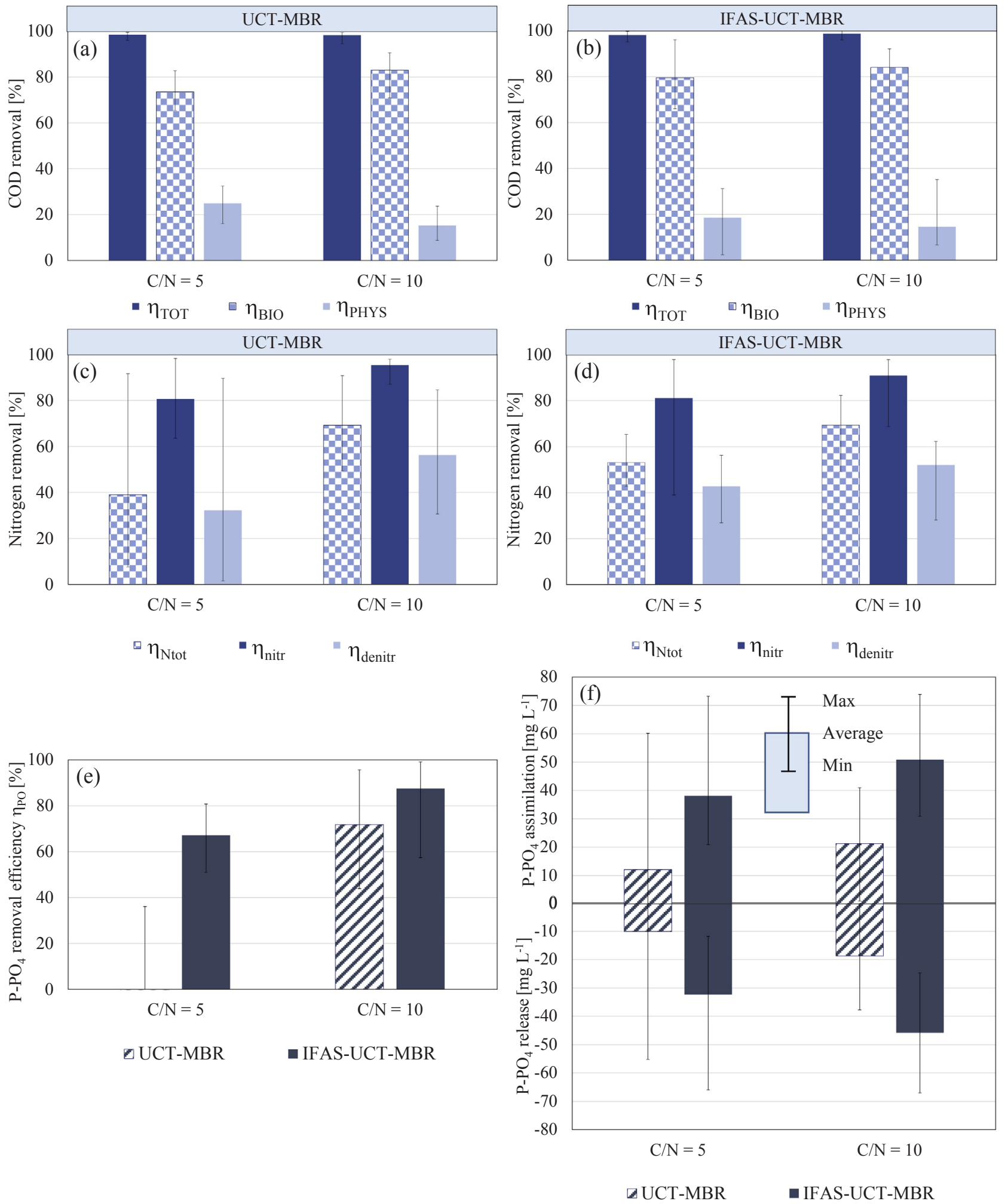

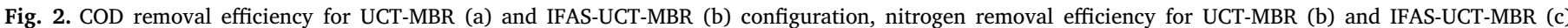
configuration, phosphorus removal efficiency for UCT-MBR and IFA-UCT-MBR configuration (e) and $\mathrm{PO}_{4}$ released and assimilated for each configuration (f).

\subsection{Respirometric batch test}

Respirometric batch tests enabled the assessment of biomass viability (either heterotrophic or autotrophic) throughout experiments. In Fig. 3, it is possible to highlight the different behaviour of the heterotrophic and autotrophic activity in the two systems. It has to be stressed that biomass samples for respirometric batch tests (both suspended biomass and biofilm) were collected from the aerobic reactor of the UCT-MBR/IFAS-UCT-MBR plants.

Concerning the heterotrophic species (mixed ordinary heterotrophs and PAO) a much higher activity of the suspended biomass in the IFASUCT-MBR configuration was observed compared with that in the pure 

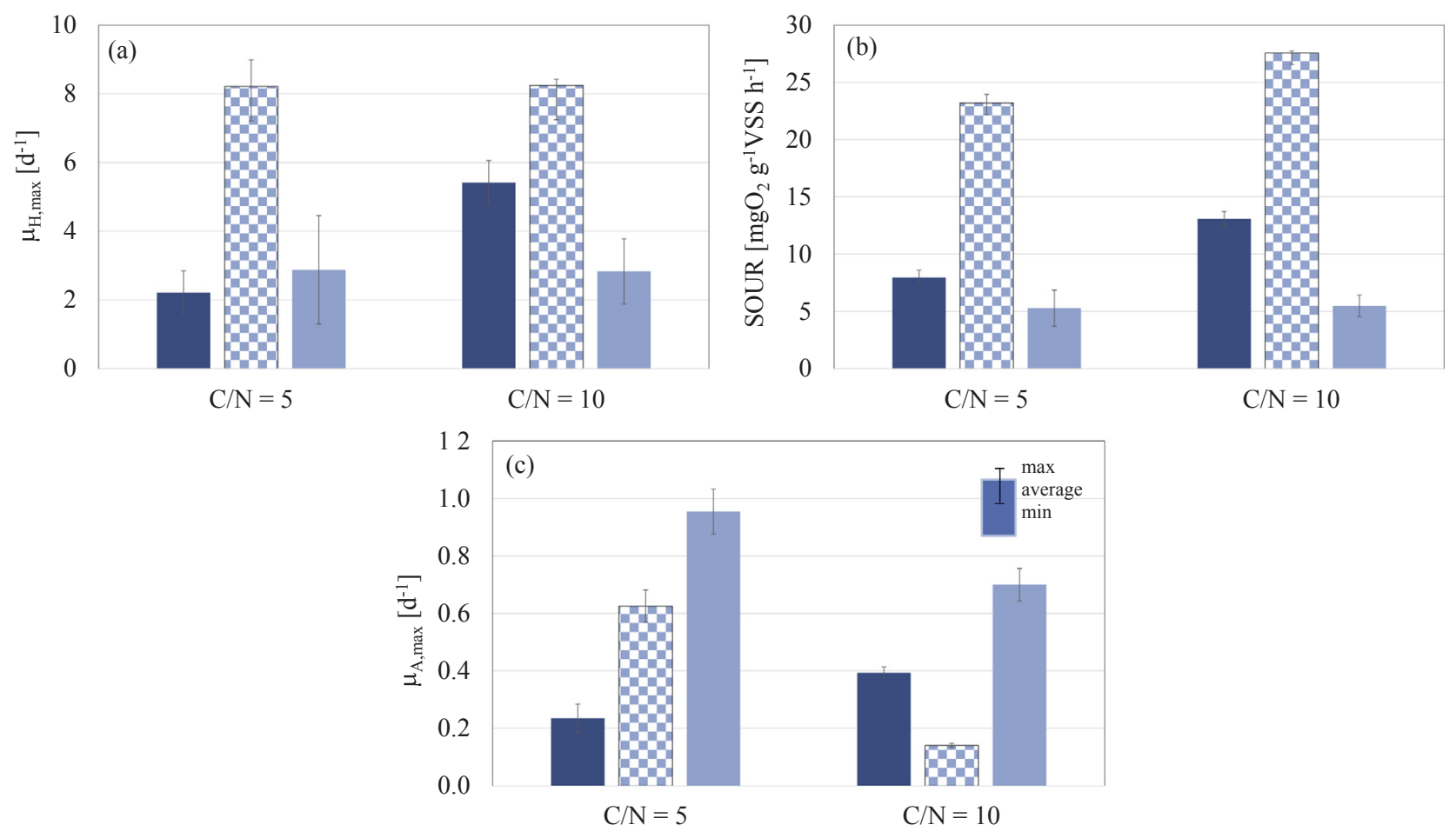

- Suspended MBR

$\square$ Suspended IFAS-UCT-MBR

\section{- Biofilm IFAS-UCT-MBR}

Fig. 3. Average values of the heterotrophic growth rate (a), specific heterotrophic respiration rates (b) and autotrophic growth rate (c) for both pilot plants.

MBR system. This result might be related to a sort of "specialization" of the biomasses in the IFAS configuration, resulting in a reduced competition between the suspended biomass and the biofilm for the availability of the different substrates. Indeed, the suspended biomass in the IFAS-UCT-MBR configuration seemed to have a greater affinity for organic matter, shown in higher growth rates (Fig. 3a) and specific respiration rates (SOUR) (Fig. 3b) compared with the UCT-MBR ones. In contrast, the heterotrophic activity within the biofilm, in terms of both growth rates and SOUR values was much lower compared to what observed for the suspended biomass. In general, the heterotrophic activity was much higher than the autotrophic one, confirming that heterotrophs are characterized by higher growth rates, thus representing the majority of the bacterial consortium.

Concerning the autotrophic activity (mixed AOB and NOB), a completely different behaviour is observed in the two pilot plants
(Table 1). Indeed, in Phase I $(\mathrm{C} / \mathrm{N}=5)$ the maximum growth rates of nitrifying species in the UCT-MBR pilot plant was much lower of both the suspended and attached biomass compared with those observed for the IFAS-UCT-MBR. During Phase I the average value of the autotrophic growth rates in the biofilm resulted four times higher than suspended biomass autotrophic grow rate $\left(0.24 \mathrm{~d}^{-1}\right.$ and $\left.0.96 \mathrm{~d}^{-1}\right)$, thus confirming the greater nitrification capability of the biofilm, characterized by high solids residence time and thus rich in nitrifying communities. Nevertheless, also the growth rates of the suspended biomass in the IFAS-UCT-MBR configuration were particularly high (much higher compared to the corresponding value of the UCT-MBR); this result could be likely due to the "seeding" effect of nitrifiers from the biofilm to the mixed liquor that contributed to enrich the activated sludge with autotrophic species. In the $\mathrm{C} / \mathrm{N}=10$ Phase II the autotrophic activity of the IFAS-UCT-MBR suspended biomass was lower compared to that of

Table 1

Average removal efficiency values for each pollutant, plant configuration and experimental phase $(\mathrm{C} / \mathrm{N}=5$ and $\mathrm{C} / \mathrm{N}=10)$.

\begin{tabular}{|c|c|c|c|c|c|c|}
\hline & \multicolumn{3}{|c|}{ Phase I $(\mathrm{C} / \mathrm{N}=5)$} & \multicolumn{3}{|c|}{ Phase II $(\mathrm{C} / \mathrm{N}=10)$} \\
\hline & \multirow{2}{*}{$\frac{\text { UCT-MBR }}{\text { Suspended }}$} & \multicolumn{2}{|l|}{ IFAS-UCT-MBR } & \multirow{2}{*}{$\begin{array}{c}\text { UCT-MBR } \\
\text { Suspended }\end{array}$} & \multicolumn{2}{|l|}{ IFAS-UCT-MBR } \\
\hline & & Suspended & Attached & & Suspended & Attached \\
\hline \multicolumn{7}{|l|}{ Heterotrophic } \\
\hline $\mathrm{Y}_{\mathrm{H}}\left[\mathrm{mgCOD} \mathrm{mg}^{-1} \mathrm{COD}\right]$ & $0.62( \pm 0.01)$ & $0.59( \pm 0.09)$ & $0.66( \pm 0.06)$ & $0.61( \pm 0.04)$ & $0.68( \pm 0.03)$ & $0.70( \pm 0.01)$ \\
\hline $\mathrm{Y}_{\text {STO }}\left[\mathrm{mgCOD} \mathrm{mg}^{-1} \mathrm{COD}\right]$ & $0.76( \pm 0.03)$ & $0.72( \pm 0.01)$ & $0.82( \pm 0.07)$ & $0.76( \pm 0.03)$ & $0.84( \pm 0.04)$ & $0.83( \pm 0.05)$ \\
\hline$\mu_{\mathrm{H}, \max }\left[\mathrm{d}^{-1}\right]$ & $2.22( \pm 0.65)$ & $8.22( \pm 0.18)$ & $2.88( \pm 1.58)$ & $5.41( \pm 0.01)$ & $8.25( \pm 0.77)$ & $2.83( \pm 0.96)$ \\
\hline $\mathrm{K}_{\mathrm{S}}\left[\mathrm{mgCOD} \mathrm{L}^{-1}\right]$ & $3.65( \pm 1.56)$ & $4.00( \pm 2.12)$ & $8.16( \pm 7.11)$ & $20.05( \pm 18.61)$ & $15.91( \pm 13.56)$ & $6.16( \pm 0.58)$ \\
\hline$b_{\mathrm{H}}\left[\mathrm{d}^{-1}\right]$ & $0.18( \pm 0.03)$ & $0.25( \pm 0.02)$ & $1.10( \pm 1.27)$ & $0.24( \pm 0.03)$ & $0.17( \pm 0.07)$ & $0.18( \pm 0.06)$ \\
\hline $\begin{array}{l}\mathrm{SOUR}_{\max }\left[\mathrm{mgO}_{2} \mathrm{~g}^{-1} \mathrm{VSSh}^{-1}\right] \\
\text { Autotrophic }\end{array}$ & $7.97( \pm 1.70)$ & $23.20( \pm 4.75)$ & $5.28( \pm 2.67)$ & $13.07( \pm 4.13)$ & $27.56( \pm 10.38)$ & $5.48( \pm 2.00)$ \\
\hline $\mathrm{Y}_{\mathrm{A}}\left[\mathrm{mgCOD} \mathrm{mg}^{-1} \mathrm{~N}\right]$ & $0.29( \pm 0.04)$ & $0.52( \pm 0.06)$ & $0.64( \pm 0.18)$ & $0.22( \pm 0.02)$ & $0.21( \pm 0.08)$ & $0.40( \pm 0.22)$ \\
\hline$\mu_{\mathrm{A}, \max }\left[\mathrm{d}^{-1}\right]$ & $0.24( \pm 0.05)$ & $0.63( \pm 0.01)$ & $0.96( \pm 0.08)$ & $0.39( \pm 0.02)$ & $0.14( \pm 0.06)$ & $0.70( \pm 0.06)$ \\
\hline $\mathrm{K}_{\mathrm{NH}}\left[\mathrm{mgNH}_{4}-\mathrm{N} \mathrm{L}^{-1}\right]$ & $1.16( \pm 0.23)$ & $3.00( \pm 0.01)$ & $2.22( \pm 0.32)$ & $3.50( \pm 0.52)$ & $1.81( \pm 1.85)$ & $0.52( \pm 0.54)$ \\
\hline Nitrif Rate $\left[\mathrm{mgNH}_{4} \mathrm{~L}^{-1} \mathrm{~h}^{-1}\right]$ & $2.04( \pm 0.83)$ & $4.77( \pm 0.08)$ & $4.29( \pm 1.31)$ & $4.12( \pm 0.35)$ & $1.58( \pm 0.93)$ & $5.78( \pm 0.30)$ \\
\hline
\end{tabular}


Table 2

Average CST and SRF for each plant configuration and experimental phase (C/N = 5 and $\mathrm{C} / \mathrm{N}=10)$.

\begin{tabular}{|c|c|c|c|c|c|}
\hline \multirow[t]{2}{*}{ Parameter } & \multirow[t]{2}{*}{ Reactor } & \multicolumn{2}{|l|}{ UCT-MBR } & \multicolumn{2}{|c|}{ IFAS-UCT-MBR } \\
\hline & & $\mathrm{C} / \mathrm{N}=5$ & $\mathrm{C} / \mathrm{N}=10$ & $\mathrm{C} / \mathrm{N}=5$ & $\mathrm{C} / \mathrm{N}=10$ \\
\hline \multirow[t]{4}{*}{ CST [s] } & Anaerobic & $14.9(1.2)$ & $15.1(1.0)$ & $16.0(2.2)$ & $14.0(4.2)$ \\
\hline & Anoxic & $17.7(1.8)$ & $18.6(1.7)$ & $25.0(7.5)$ & $21.5(8.5)$ \\
\hline & Aerobic & $16.9(4.3)$ & $16.1(1.4)$ & $22.6(6.3)$ & $23.2(6.0)$ \\
\hline & MBR & $18.0(2.0)$ & $19.9(1.8)$ & $41.3(14.4)$ & $34.2(13.8)$ \\
\hline \multirow[t]{4}{*}{$\operatorname{SRF}\left[10^{12} \mathrm{~m} \mathrm{~kg}^{-1}\right]$} & Anaerobic & $2.7(0.8)$ & $3.3(0.8)$ & $5.3(4.5)$ & $5.3(1.4)$ \\
\hline & Anoxic & $2.8(0.8)$ & $4.1(0.6)$ & $4.1(0.7)$ & $5.9(2.4)$ \\
\hline & Aerobic & $3.0(0.4)$ & $4.0(0.9)$ & $4.0(1.7)$ & $3.5(1.7)$ \\
\hline & MBR & $2.8(0.8)$ & $3.6(0.6)$ & $4.8(1.4)$ & $3.6(3.1)$ \\
\hline
\end{tabular}

Standard deviation in square brackets.

the pure MBR system. This is possibly due to heterotrophic organisms growing over the nitrifiers on the carriers due to the greater availability of biodegradable organics thereby increasing the diffusional resistance of ammonia or oxygen into the biofilm on the carriers. However, the presence of the biofilm, characterized by high nitrification ability, contributed to sustain nitrification also in this phase, highlighting the great robustness of the IFAS-UCT-MBR configuration. It is worth noting that the present study enabled to discriminate the respirometry activity of biofilm from that of suspended biomass. In contrast, the few previous studies that investigated the kinetics of heterotrophic and autotrophic bacteria in MBR and IFAS-MBR systems for nutrients removal often focused on the suspended biomass activity only, without providing any data for the biofilm activity (Leyva-Díaz et al., 2013). This circumstance makes rather difficult to compare the results of the present study with literature data.

\subsection{Sludge dewaterability}

Average values of achieved CST and SRF are summarized in Table 2.

From the results in Table 2, it can be seen that the sludge dewaterability deteriorated by the presence of the attached biomass in the IFAS configuration. This is likely due to the presence of detached biofilm which contributed to increase the average CST and SRF. On average, the mean measured CST in the UCT-MBR over each reactor was $17 \mathrm{~s}$ and in the IFAS-UCT-MBR it was $25 \mathrm{~s}$. Similarly, the SRF averaged over each reactor of UCT-MBR configuration was $3.3 \cdot 10^{12} \mathrm{~m} \mathrm{~kg}^{-1}$, while in the IFAS-UCT-MBR configuration the average SRF was $4.6 \cdot 10^{12} \mathrm{~m} \mathrm{~kg}^{-1}$. These results suggest that the detached biofilm presence in suspended sludge affect the dewaterability features of the mixed liquor.

\subsection{Extracellular polymeric substances}

Fig. 4 shows the fractionation of the average weighted sum of the normalized $\mathrm{EPS}_{\mathrm{T}}$ (expressed as \%TSS) for each plant configuration and investigated $\mathrm{C} / \mathrm{N}$, whilst in Table 3 the average weighted sum, not normalized, of EPS $\mathrm{T}_{\mathrm{T}}$ is reported. In details, $\mathrm{EPS}_{\mathrm{T}}$ is composed by soluble microbial products (SMP), measured as carbohydrates as well as protein, and bound EPS, measured in protein and carbohydrates, namely $\mathrm{EPS}_{\mathrm{T}}$ represents the sum of SMP $\mathrm{p}, \mathrm{SMP}_{\mathrm{c}}, \mathrm{EPS}_{\mathrm{p}}, \mathrm{EPS}_{\mathrm{c}}$.

Results reported in Fig. 4 show that despite the highest $\mathrm{EPS}_{\mathrm{T}}$ was EPSp for all $\mathrm{C} / \mathrm{N}$ and configurations, a different fractionation occurred during the investigated cases.

More precisely, a substantial increase of the SMP (both SMPc and SMPp) occurred during the IFAS-UCT-MBR operation. The average SMP value during the UCT-MBR operation was equal to $0.5 \%$, while during the IFAS-UCT-MBR operation was equal to $8.6 \%$. As discussed below this result is of particular interest to the issue of membrane fouling.

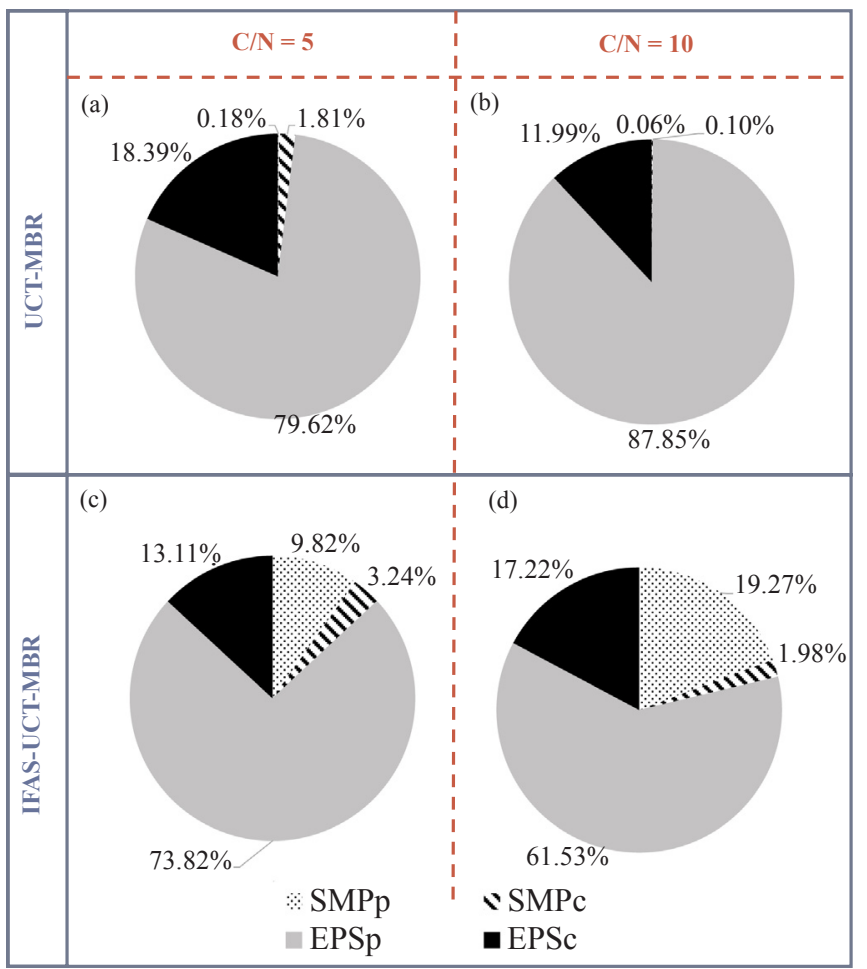

Fig. 4. Fractionation of the average weighted sum of the normalized $\mathrm{EPS}_{\mathrm{T}}$ (expressed as $\mathrm{mg} / \mathrm{gTSS}$ ) for the UCT-MBR configuration during the phase at C/ $\mathrm{N}$ equal to 5 (a) and 10 (b) and for the IFAS-UCT-MBR configuration during the phase at $\mathrm{C} / \mathrm{N}$ equal to 5 (c) and $10(\mathrm{~d})$.

\subsection{Membrane fouling}

Fig. 5 shows the results of the total membrane resistance $\left(R_{T}\right)$ and fouling rate (FR) for each configuration. In Fig. 5e the results of the in series resistance model at the end of each phase and for each configuration are also shown.

The average $R_{T}$ value was quite stable during the two monitored phases for both configurations. For the UCT-MBR configuration the average $\mathrm{R}_{\mathrm{T}}$ was $5.4 \times 10^{12} \mathrm{~m}^{-1}$ and $7.6 \times 10^{12} \mathrm{~m}^{-1}$ during the Phases I $(\mathrm{C} / \mathrm{N}=5)$ and II $(\mathrm{C} / \mathrm{N}=10)$ respectively. For the IFAS-UCT-MBR configuration, the average $\mathrm{R}_{\mathrm{T}}$ was $9.88 \times 10^{12} \mathrm{~m}^{-1}$ and $13.2 \times 10^{12} \mathrm{~m}^{-1}$ during Phase I and II respectively.

During the IFAS-UCT-MBR a high fouling tendency was noticed. In details, during the IFAS-UCT-MBR monitoring nine physical and four chemical (sodium hypochlorite based) cleanings were performed in order to keep the total resistance within the $\mathrm{R}_{\mathrm{T}}$ slot suggested by the membrane module manufactures. Conversely, during the UCT-MBR the maintenance of membrane module consisted of five physical cleanings. Similarly, the average FR was equal to $1.7 \times 10^{12} \mathrm{~m}^{-1} \mathrm{~d}^{-1}$ and 
Table 3

Average weighted sum, not normalized, of EPS $\mathrm{T}_{\mathrm{T}}$ fraction, protein and carbohydrates, (expressed as mg/gTSS) for both configuration during the both phases.

\begin{tabular}{|c|c|c|c|c|}
\hline & $\mathrm{SMP}_{\mathrm{P}}$ & $\mathrm{SMP}_{\mathrm{C}}$ & $\mathrm{EPS}_{\mathrm{P}}$ & $\mathrm{EPS}_{\mathrm{C}}$ \\
\hline & mgEPS/gTSS & mgEPS/gTSS & mgEPS/gTSS & mgEPS/gTSS \\
\hline \multicolumn{5}{|l|}{ UCT-MBR } \\
\hline \multirow[t]{6}{*}{$\mathrm{C} / \mathrm{N}=10$} & 0 & 3 & 526 & 61 \\
\hline & 0 & 0 & 434 & 99 \\
\hline & 0 & 0 & 479 & 63 \\
\hline & 0 & 0 & 332 & 67 \\
\hline & 2 & 0 & 452 & 44 \\
\hline & 0 & 0 & 362 & 20 \\
\hline \multirow[t]{5}{*}{$\mathrm{C} / \mathrm{N}=5$} & 0 & 7 & 389 & 167 \\
\hline & 0 & 15 & 350 & 77 \\
\hline & 0 & 0 & 225 & 18 \\
\hline & 0 & 1 & 247 & 34 \\
\hline & 4 & 13 & 390 & 74 \\
\hline \multicolumn{5}{|c|}{ IFAS -UCT-MBR } \\
\hline \multirow[t]{9}{*}{$\mathrm{C} / \mathrm{N}=5$} & 265 & 59 & 850 & 82 \\
\hline & 147 & 103 & 507 & 157 \\
\hline & 90 & 6 & 688 & 97 \\
\hline & 47 & 12 & 557 & 115 \\
\hline & 1 & 0 & 609 & 101 \\
\hline & 27 & 0 & 653 & 135 \\
\hline & 24 & 18 & 658 & 115 \\
\hline & - & 20 & 542 & 191 \\
\hline & 3 & 12 & 439 & 211 \\
\hline \multirow[t]{3}{*}{$\mathrm{C} / \mathrm{N}=10$} & - & 9 & 648 & 176 \\
\hline & 7 & 26 & 517 & 93 \\
\hline & 617 & 40 & 1184 & 261 \\
\hline
\end{tabular}

$3.0 \times 10^{12} \mathrm{~m}^{-1} \mathrm{~d}^{-1}$ for the UCT-MBR and IFAS-UCT-MBR configuration, respectively (Fig. 5c-d). This result is likely due to two reasons: (i) the increase of SMP which promoted the irreversible fouling and (ii) the increase of sludge viscosity due to the sloughed biofilm in the suspended solids. The loosely bound EPS (LB-EPS) of the external biofilm layers could be easily eroded thus released as SMP in the bulk liquid. This circumstance could have worsened the filtration properties of the membrane. Moreover, at the same average temperature $\left(26^{\circ} \mathrm{C}\right)$, the average sludge viscosity was 2.2 and $2.6 \mathrm{mPa}$ s for UCT-MBR and IFASUCT-MBR, respectively.

Fig. 5e shows that the highest fouling fraction was always due to the irreversible cake $\left(\mathrm{R}_{\mathrm{C}, \text { irr }}\right)$. However, from the results discussed above, an increase of the irreversible cake fouling fraction was observed in the IFAS-UCT-MBR mainly during the Phase $\mathrm{I}$ at $\mathrm{C} / \mathrm{N}=5$. Indeed, during this phase in the IFAS-UCT-MBR configuration, $\mathrm{R}_{\mathrm{C} \text {,irr }}$ was $18 \%$ of the total membrane fouling, $\mathrm{R}_{\mathrm{T}}$ (Fig. 5e.3). This value was one order of magnitude higher than that of the UCT-MBR system (average value $\mathrm{R}_{\mathrm{c} \text {,irr }}=1.3 \%$ of total $\mathrm{R}_{\mathrm{T}}$ ) (Fig. 5e.1 and Fig. 5e.2). The results obtained here could seem contrasting with the main literature where it often demonstrated that the addition of biofilm carriers inside the MBR allow to retard the membrane fouling thanks to the mechanically enhanced scouring effect on membrane surface due to the carrier (among others, Jin et al., 2013; Fu et al., 2016). However, as recently emphasized by Meng et al. (2017) the results summarized in literature related to the role of carriers in fouling development vary significantly and even are contradictory to one another. Literature often attributes the fouling mitigation to the mechanical scouring effect of carriers often neglecting the changes in biomass characteristics which could have a negative effect on membrane fouling (Meng et al., 2017).

\section{6. $\mathrm{N}_{2} \mathrm{O}$ concentration and emission factor}

During both investigations, carried out with both configurations (i.e. UCT-MBR and IFAS-UCT-MBR), an intensive experimental campaign to measure the nitrous oxide formation and emission phenomena was carried out. Average nitrous oxide concentrations measured in both liquid and gaseous phases of each reactor are shown in Fig. 6 coupled with the emission factor.

In details, samples collected from the headspace of each reactor (Fig. $6 \mathrm{a}$ and b), show low $\mathrm{N}_{2} \mathrm{O}$ concentrations during each phase of both investigated configurations. The highest average concentration measured during the whole experimentation (both $\mathrm{C} / \mathrm{N}$ and both layout) equal to $71 \mu \mathrm{g} \mathrm{N} \mathrm{N}_{2} \mathrm{O}-\mathrm{N} \mathrm{L}^{-1}$, occurred in the aerobic reactor of the IFASUCT-MBR system during $\mathrm{C} / \mathrm{N}=10$ Phase II. The highest average concentration $\left(54 \mu \mathrm{g} \mathrm{N}_{2} \mathrm{O}-\mathrm{N} \mathrm{L}^{-1}\right)$ occurred in the anaerobic reactor of the UCT-MBR layout during the $\mathrm{C} / \mathrm{N}=5$ Phase $\mathrm{I}$.

In general, the high $\mathrm{N}_{2} \mathrm{O}$ concentrations measured in the headspace resulted in lower than $\mathrm{N}_{2} \mathrm{O}$ concentrations in the liquid bulk (Fig. 6c and d). In detail, the highest dissolved $\mathrm{N}_{2} \mathrm{O}$ concentration during both phases occurred in the IFAS-UCT-MBR system (Fig. 6d). During C/ $\mathrm{N}=5$ the highest average $\mathrm{N}_{2} \mathrm{O}$ concentration was in the aerobic reactor at $101 \mu \mathrm{g} \mathrm{N} \mathrm{N}_{2} \mathrm{O}-\mathrm{N} \mathrm{L}^{-1}$, while during $\mathrm{C} / \mathrm{N}=10$ the highest average $\mathrm{N}_{2} \mathrm{O}$ concentration was measured in the MBR reactor at $333 \mu \mathrm{g} \mathrm{N} \mathrm{N}_{2} \mathrm{O}-\mathrm{N} \mathrm{L}^{-1}$.

Moreover, by comparing results of UCT-MBR and IFAS-UCT-MBR systems, it can be observed that when the carriers were not present (Fig. 6a and c), the $\mathrm{N}_{2} \mathrm{O}$ concentration (both dissolved and gaseous) were continuously higher during $\mathrm{C} / \mathrm{N}=5$ Phase 2 . This confirms that when limitation in the nitrogen transformation processes occur (such as low carbon availability), the nitrous oxide production increases (Kampschreur et al., 2009). In contrast, in the IFAS-UCT-MBR system it was not possible to identify a clear trend of both dissolved and headspace nitrous oxide concentrations. This is probably due to the presence of suspended carriers in the IFAS layout that likely modify the biological equilibrium that occurs in the whole plant.

Despite the higher nitrous oxide concentrations measured in both liquid and gaseous phase of the IFAS-UCT-MBR system, the effect of the co-presence of attached and suspended biomass in the IFAS led to differences in the $\mathrm{N}_{2} \mathrm{O}$ average emission factor, as reported in Fig. 6e-f.

In detail, the $\mathrm{N}_{2} \mathrm{O}$ emission factors (\% of influent $\mathrm{N}$ emitted as $\mathrm{N}_{2} \mathrm{O}$ ) in both systems were affected by the presence of aeration devices. Indeed, emission factors in the aerobic and MBR reactors were up to two orders of magnitude higher than for the anaerobic and anoxic reactors. This result is consistent with previous observations that show an increase of the $\mathrm{N}_{2} \mathrm{O}$ stripping due to the air supplied in order to maintain the aerobic environment (aerobic reactor) as well as to mitigate the membrane fouling (MBR reactor) (Mannina et al., 2017a, 2017b).

Despite the higher supplied oxygen to the IFAS-UCT-MBR, due to the carrier mobilization requirements, the UCT-MBR aerated reactors emitted more than the IFAS-UCT-MBR ones: $3.5 \%$ and $0.5 \%$ of influent nitrogen respectively. Such circumstance, as noticeable by Fig. 6e and f, is likely ascribable to the biofilm presence. Indeed the co-presence of both attached and suspended biomass resulted in a clear improvement of biological performances and thus in a drastic reduction of $\mathrm{N}_{2} \mathrm{O}$ production/emission (Leyva-Díaz et al., 2013). The latter represents a useful insight for reducing the $\mathrm{N}_{2} \mathrm{O}$, and thus the GHG, emission from a wastewater treatment plant. Indeed, in the light of these results, adding carriers could be a good strategy aimed at improving the biological nutrient removal efficiency and reducing, at the same time, the GHGs emission.

\section{Conclusion}

An experimental campaign aimed at comparing UCT-MBR and IFASUCT-MBR by varying the influent $\mathrm{C} / \mathrm{N}$ ratio was carried out. The main findings of this study are:

- IFAS-UCT-MBR showed high potentiality since it provided the highest removal efficiency for carbon, nitrogen and phosphorous throughout the investigation.

- Nitrous oxide emission factor resulted lower for the IFAS-UCT-MBR, thus showing a role played by biofilm in mitigating the $\mathrm{N}_{2} \mathrm{O}$ 

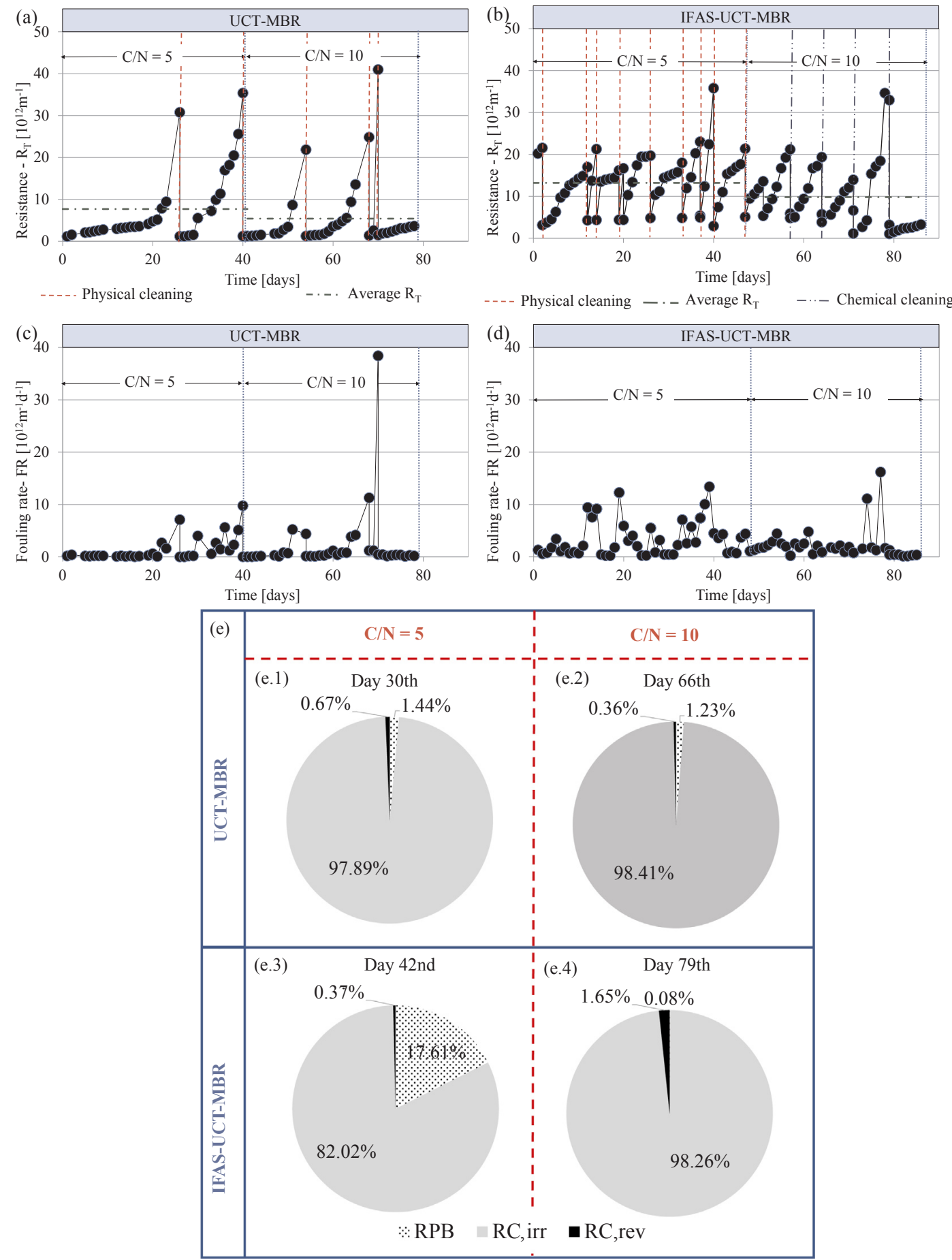

Fig. 5. Total membrane resistance $\left(R_{T}\right)$ for the UCT-MBR (a) and IFAS-UCT-MBR (b) configuration; fouling rate (FR) for the UCT-MBR (c) and IFAS-UCT-MBR (d) configuration; total membrane resistance $\left(\mathrm{R}_{\mathrm{T}}\right)$ fractionation for the UCT-MBR (e.1, e.2) and IFAS-UCT-MBR (e.3, e.4) configuration ( $\mathrm{R}_{\mathrm{PB}}=$ Resistence due to pore blocking, $\mathrm{R}_{\mathrm{c}, \text { irr }}=$ irreversible cake fouling and $\mathrm{R}_{\mathrm{c}, \mathrm{rev}}=$ reversible fouling).

emission.

- The membrane fouling was monitored in both layout and a greater tendency occurred during IFAS-UCT-MBR.

The latter finding can affect the GHG production indirectly; indeed, energy demand for solid liquid separation increases as far as the membrane fouling increases.

\section{Acknowledgments}

This work forms part of a research project supported by grant of the Italian Ministry of Education, University and Research (MIUR) through the Research project of national interest PRIN2012 (D.M. 28 dicembre 2012 n. 957/Ric - Prot. 2012PTZAMC) entitled "Energy consumption and GreenHouse Gas (GHG) emissions in the wastewater treatment plants: a decision support system for planning and management http://ghgfromwwtp.unipa.it" in which the first author is the Principal Investigator. Giorgio Mannina is Fulbright research Fellow at Columbia 
(a)

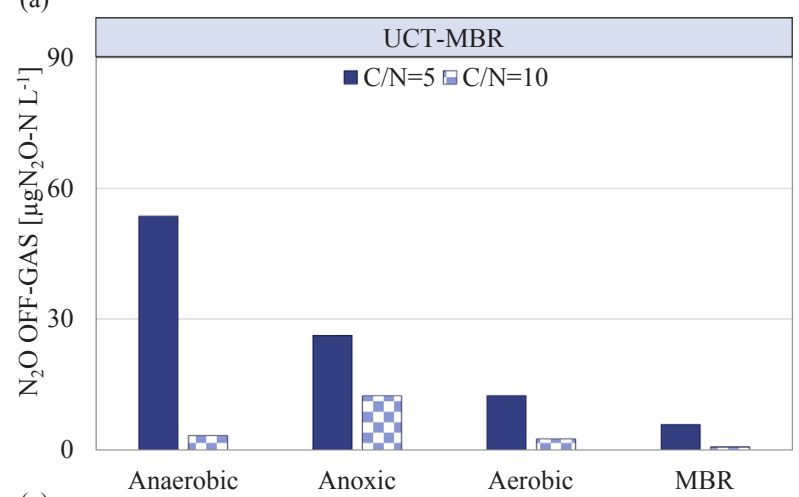

(c)

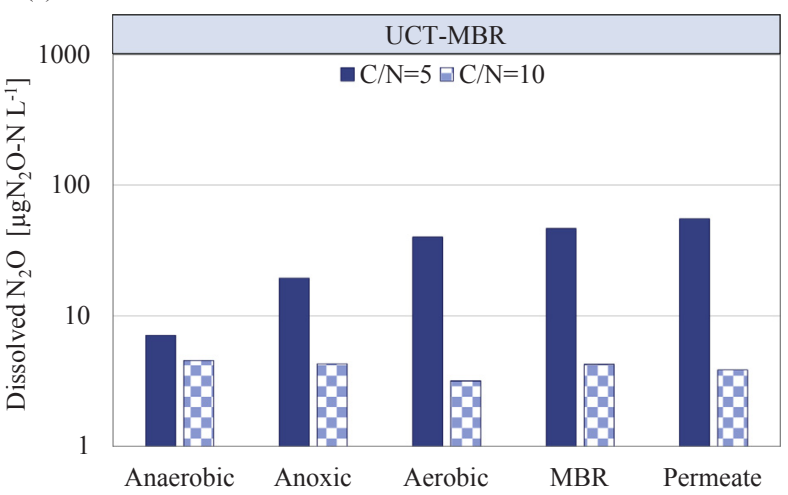

(e)

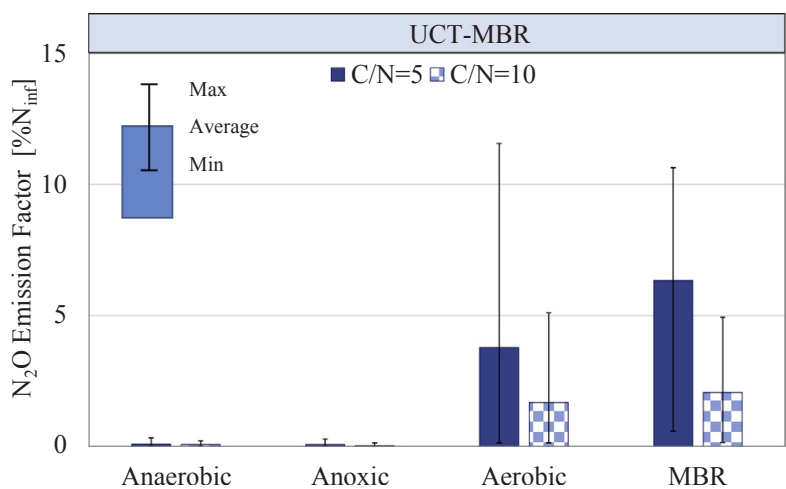

(b)

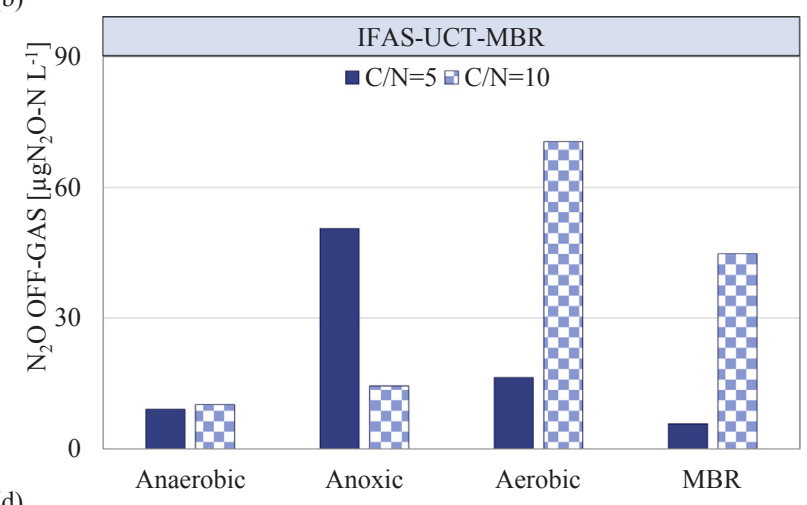

(d)

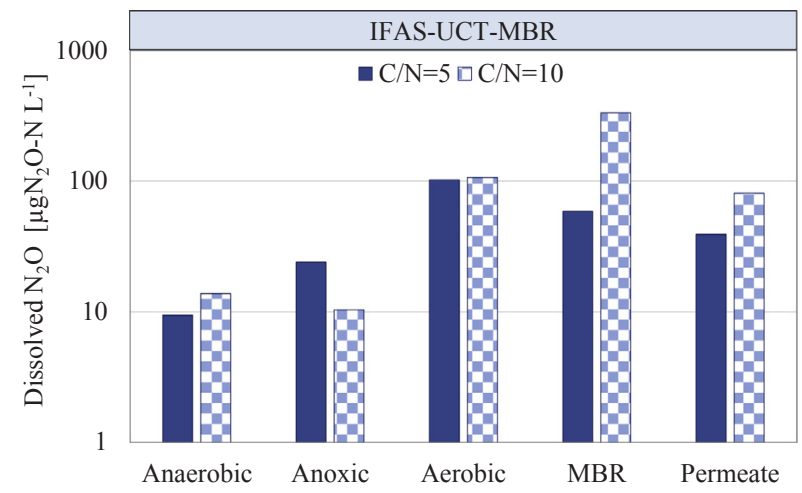

(f)

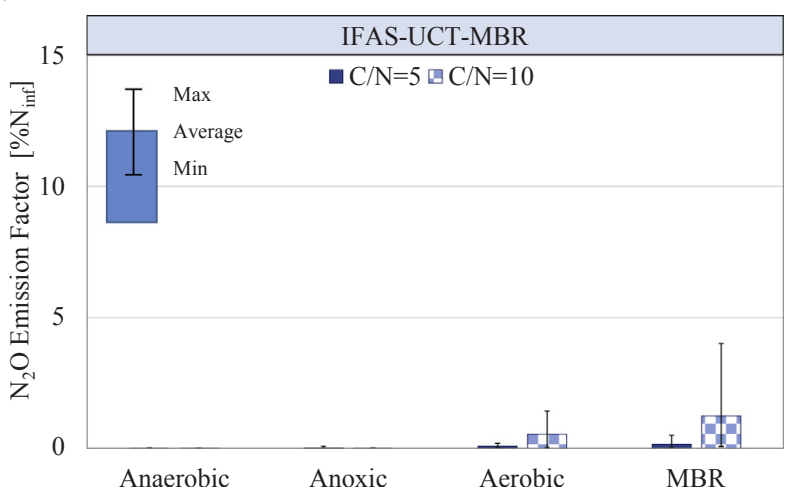

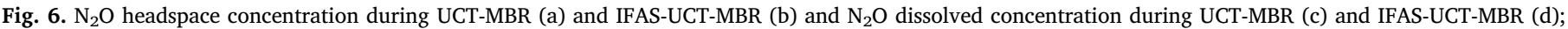
average Nitrous oxide Emission factors assessed during UCT-MBR (e) and during IFAS-UCT-MBR (f) for both investigated C/N values.

University, New York, USA.

\section{References}

APHA, 2012. Standard Methods for the Examination of Water and Wastewater, twentysecond ed. American Public Health Association, Washington.

Capodici, M., Mannina, G., Torregrossa, M., 2016. Waste activated sludge dewaterability: comparative evaluation of sludge derived from CAS and MBR systems. Desalin. Water Treat. 57, 22917-22925. https://doi.org/10.1080/19443994.2016.1180478.

Cuevas-Rodríguez, G., Cervantes-Avilés, P., Torres-Chávez, I., Bernal-Martínez, A., 2015. Evaluation of different configurations of hybrid membrane bioreactors for treatment of domestic wastewater. Water Sci. Technol. 71, 338-346. https://doi.org/10.2166/ wst.2014.481.

Di Trapani, D., Di Bella, G., Mannina, G., Torregrossa, M., Viviani, G., 2015. Effect of C/N shock variation on the performances of a moving bed membrane bioreactor. Bioresour. Technol. 189, 250-257. https://doi.org/10.1016/j.biortech.2015.03.143.

Di Trapani, D., Di Bella, G., Mannina, G., Torregrossa, M., Viviani, G., 2014. Comparison between moving bed-membrane bioreactor (MB-MBR) and membrane bioreactor (MBR) systems: influence of wastewater salinity variation. Bioresour. Technol. 162, 60-69. https://doi.org/10.1016/j.biortech.2014.03.126.

Feng, Z.J., Wu, M., Sun, M.X., Liu, H.Y., Zhang, Y.Z., Dai, J., 2016. The effects of different carriers on removal performance and membrane fouling by HMBR in treating sewage with low carbon-to-nitrogen ratio. Process Saf. Environ. Protect. 102, 768-776. https://doi.org/10.1016/j.psep.2016.06.019.
Fu, Z., Yang, F., Zhou, F., Xue, Y., 2009. Control of COD/N ratio for nutrient removal in a modified membrane bioreactor (MBR) treating high strength wastewater. Bioresour. Technol. 100, 136-141. https://doi.org/10.1016/j.biortech.2008.06.006.

Fu, C., Bi, X.J., Ng, H.Y., 2016. Effects of bio-carriers on membrane fouling mitigation in moving bed membrane bioreactor. J. Membr. Sci. 499, 134-142. https://doi.org/10. 1016/j.memsci.2015.10.052.

Jin, L., Ong, S.L., Ng, H.Y., 2013. Fouling control mechanism by suspended biofilm carriers addition in submerged ceramic membrane bioreactors. J. Membr. Sci. 427, 250-258. https://doi.org/10.1016/j.memsci.2012.09.016.

Kampschreur, M.J., Temmink, H., Kleerebezem, R., Jetten, M.S.M., van Loosdrecht, M.C.M., 2009. Nitrous oxide emission during wastewater treatment. Water Res. 43, 4093-4103. https://doi.org/10.1016/j.watres.2009.03.001.

Kimochi, Y., Inamori, Y., Mizuochi, M., Xu, K.Q., Matsumura, M., 1998. Nitrogen removal and $\mathrm{N}_{2} \mathrm{O}$ emission in a full-scale domestic wastewater treatment plant with intermittent aeration. J. Ferment. Bioeng. 86, 202-206. https://doi.org/10.1016/S0922338X(98)80114-1.

Leiknes, T., Ødegaard, H., 2007. The development of a biofilm membrane bioreactor Desalination 202, 135-143. https://doi.org/10.1016/j.desal.2005.12.049.

Leyva-Díaz, J.C., Calderón, K., Rodríguez, F.A., González-López, J., Hontoria, E., Poyatos, J.M., 2013. Comparative kinetic study between moving bed biofilm reactor-membrane bioreactor and membrane bioreactor systems and their influence on organic matter and nutrients removal. Biochem. Eng. J. 77, 28-40. https://doi.org/10.1016/ j.bej.2013.04.023.

Leyva-Diaz, J.C., Poyatos, J.M., 2015. Start-Up of membrane bioreactor and hybrid moving bed biofilm reactor-Membrane bioreactor: kinetic study. Water Sci. Technol. 
72, 1948-1953. https://doi.org/10.2166/wst.2015.419.

Leyva-Díaz, J.C., Martín-Pascual, J., Poyatos, J.M., 2016a. Moving bed biofilm reactor to treat wastewater. Int. J. Environ. Sci. Technol. 881-910. https://doi.org/10.1007/ s13762-016-1169-y.

Leyva-Díaz, J.C., Mũnío, M.M., González-López, J., Poyatos, J.M., 2016b. Anaerobic/ anoxic/oxic configuration in hybrid moving bed biofilm reactor-membrane bioreactor for nutrient removal from municipal wastewater. Ecol. Eng. 91, 449-458. https://doi.org/10.1016/j.ecoleng.2016.03.006.

Mannina, G., Capodici, M., Cosenza, A., Di Trapani, D., 2016. Carbon and nutrient biological removal in a University of Cape Town membrane bioreactor: analysis of a pilot plant operated under two different C/N ratios. Chem. Eng. J. 296, 289-299. https://doi.org/10.1016/j.cej.2016.03.114.

Mannina, G., Capodici, M., Cosenza, A., Di Trapani, D., Laudicina, V.A., Ødegaard, H., 2017a. Nitrous oxide from moving bed based integrated fixed film activated sludge membrane bioreactors. J. Environ. Manag. 187, 96-102. https://doi.org/10.1016/j. jenvman.2016.11.025.

Mannina, G., Capodici, M., Cosenza, A., Di Trapani, D., van Loosdrecht, M., 2017b. Nitrous oxide emission in a University of Cape Town membrane bioreactor: the effect of carbon to nitrogen ratio. J. Clean. Prod. 149, 180-190. https://doi.org/10.1016/j. jclepro.2017.02.089.

Mannina, G., Ekama, G.A., Capodici, M., Cosenza, A., Di Trapani, D., Ødegaard, H., 2017 c. Moving bed membrane bioreactors for carbon and nutrient removal: the effect of C/N variation. Biochem. Eng. J. 125, 31-40. https://doi.org/10.1016/j.bej.2017. 05.005 .

Meng, F., Zhang, S., Oh, Y., Zhou, Z., Shin, H.-S., Chae, S.-R., 2017. Fouling in membrane bioreactors: an updated review. Water Res. 114, 151-180. https://doi.org/10.1016/j. watres.2017.02.006.

Naessens, W., Maere, T., Nopens, I., 2012. Critical review of membrane bioreactor models - Part 1: biokinetic and filtration models. Bioresour. Technol. 122, 95-106. https:// doi.org/10.1016/j.biortech.2012.05.070

Ødegaard, H., Christensson, M., Sørensen, K., 2014. Hybrid systems. In: Wanner, J., J.D (Eds.), Activated Sludge 100 Years - and Counting. IWA publishing, London.

Ødegaard, H., 2017. New applications for MBBR and IFAS systems. In: In: Mannina, G. (Ed.), Frontiers in Wastewater Treatment and Modelling. Book Series: Lecture Notes in Civil Engineering, vol. 4. Springer Int. Publ, AG, Switzerland, pp. 499-507.

Onnis-Hayden, A., Dahr, D., Johnson, C., Schramm, A., Gu, A.Z., 2007. Kinetics and nitrifying populations in nitrogen removal processes at a full-scale integrated fixed-film activated sludge (IFAS) plant. In: WEFTEC 2007. Water Environment Federation.

Rusten, B., Nielsen, M., Welander, T., Rasmussen, V., 2003. Increasing the capacity of activated sludge plants by using AS/MBBR hybrid process with Kaldnes biofilm carriers. In: 5th IWA Conference on Biofilms Systems. Cape Town, South Africa.

Todt, D., Dörsch, P., 2016. Mechanism leading to $\mathrm{N}_{2} \mathrm{O}$ production in waste water treating biofilm systems. Rev. Environ. Sci. Biotechnol. 15, 355-378. https://doi.org/10. 1007/s11157-016-9401-2.

Tsuneda, S., Mikami, M., Kimochi, Y., Hirata, A., 2005. Effect of salinity on nitrous oxide emission in the biological nitrogen removal process for industrial wastewater. J. Hazard Mater. 119, 93-98. https://doi.org/10.1016/j.jhazmat.2004.10.025.

Wang, X.J., Xia, S.Q., Chen, L., Zhao, J.F., Renault, N.J., Chovelon, J.M., 2006. Nutrients removal from municipal wastewater by chemical precipitation in a moving bed biofilm reactor. Process Biochem. 41, 824-828. https://doi.org/10.1016/j.procbio. 2005.10.015.

Wanner, J., 2002. Control of filamentous bulking in activated sludge. In: In: Bitton, G. (Ed.), Encyclopedia of Environmental Microbiology, vols. 1306-1315. John Wiley \& Sons Inc, New York USA, pp. 2002.

Yang, W., Syed, W., Zhou, H., 2014. Comparative study on membrane fouling between membrane-coupled moving bed biofilm reactor and conventional membrane bioreactor for municipal wastewater treatment. Water Sci. Technol. 69, 1021-1027. https://doi.org/10.2166/wst.2013.823 